\title{
RIGHT TO FOOD AND "TRAGEDY" OF THE COMMONS
}

DIREITO À ALIMENTAÇÃO E “TRAGÉDLA” DOS BENS COMUNS

Antonio Gusmai *

\begin{abstract}
Resumo: Sem pretender ser exaustivo, este trabalho objetiva verificar a possibilidade de considerar o alimento um bem comum sob a perspectiva jurídica. Em efeito, a doutrina constitucional italiana parece não ter considerado com a devida atenção este aspecto particular, em nada irrelevante, nos estudos sobre os bens comuns. Para tanto, serão oferecidas breves reflexões na perspectiva constitucional, com o propósito de demonstrar as dificuldades que podem ser encontradas ao se levar em consideração tal hipótese, isto é, ao se considerar o direito à alimentação não apenas na esfera privada, mas na dimensão pública protegida pela Constituição. Após identificar alguns aspectos críticos das doutrinas sobre os bens comuns, será examinada a possibilidade de garantir a todas as pessoas o direito fundamental à alimentação, através dos serviços de utilidade pública disponibilizados pelo governo local. Diversamente, deixar às leis do mercado a garantia do alimento comporta o risco de legitimar o "paradoxo jurídico" que a ordem constitucional (especialmente a italiana) por nenhum motivo pode tolerar.
\end{abstract}

Palavras-chave: Bens comuns. Constituição italiana. Constitucionalismo moderno. Novo constitucionalismo Andino. Direito à alimentação. Direito à água.

\begin{abstract}
Without claiming of exhaustivity,this work aims at verifying the possibility to consider food as a common good from a juridical perspective. In fact, it seems that so farthe Italian constitutional doctrine has not covered this particular aspect- anything but irrelevant - in the studies dealing with these theories. Therefore, I will try hereafter to make some short reflections from a constitutional perspective, with the purpose of showing the quantity of difficulties that can be encountered if one considers this hypothesis, i.e. if one places the right to food not only beyond the «private», but also beyond the «public» dimension provided by the Constitution. Ultimately, after identifying some critical aspects of the doctrines of common goods, I will try to examine the possibility to guarantee all peoplethe fundamental right to access to food by using the «public utilities made available by the local government». Otherwise, if we let the laws of the market be the
\end{abstract}

* Research Fellow/University of Salento/L.A.I.R. Group.E-mail: ant.gusmai@gmail.com 
ones that can guarantee food, we risk legitimizing a "juridical paradox" that the constitutional order (at least the Italian one) by no means can tolerate.

Keywords: Common goods. Italian Constitution. Modern constitutionalism. Andean nuevo constitucionalismo-right to food. Right to water. Public utilities made available by the local government.

\section{INTRODUCTORY NOTES}

The theme of «common goods» has lately reached a relevant position among the studies of jurists, especially since it was formally introduced by the Rodotà Committee's report ${ }^{1}$.

The term «common goods» is often used with respect to goods that each individual should be able to afford. Should we use the words of the abovementioned committee, common goods «express functional utility to the exercise of fundamental rightsas well as the free development of a person» and therefore «must be protected and safeguarded by the legal system, also for the benefit of future generations». Still according to the Committee, common goods are, inter alia, «rivers, streams and their springs; lakes and other waters; the air; parksas defined by law, forests and wooded areas; mountainous areas at a high altitude, glaciers and perpetual snow; shoresand coastlines declared environmental reserves; protected wild flora and fauna; archaeological, cultural and environmental goods and other protected areas of the landscape» ${ }^{2}$.

They are mostly environmental goods, even if artificial resources are included: historic and cultural heritage, physical infrastructures (aqueducts, routes of communication),computer resources (the Internet or other networks) or immaterialgoods such as knowledge, provided that they are qualified, as we will see shortly,by a certain modality ofgovernance andmanagement.

Therefore, despite the complex heterogeneity ${ }^{3}$ of the commons, it seems that their juridical importance can be expressed as follows: the conservation and the reproduction of these goods, be they global or local, material or immaterial, is a necessary condition to maintain a democratic social order ${ }^{4}$. 
Due to its nature, the theme dealt with arouses interest and is subject to a multidisciplinary approach: many speculations are focused on theoretical and philosophical questions (either as scientific analysis or with purposes that are merely political or educational), but many other analyze the economical and juridical aspects more specifically.

In order to narrow the scope of the analysis for a theme that is so complex and boundless, the following pages will briefly deal with 3 specific questions from a constitutional perspective, without claiming of exhaustivity. First, the juridical significance of the economic theory of the commons; second, the constitutional consequences of this doctrine; ultimately, a possible explanation of the reason why food should not be considered to be a common good, but rather asocial good.

\section{THE JURIDICAL SIGNIFICANCE OF THE ECONOMIC THEORIES OF THE COMMONS}

The economic theory of the commons has a mother and a father.

The father, Garrett Hardin, had hypothesized, in a successful article about the «tragedy of the commons», that a coercive regulation could be a useful solution to control the individual use of scarce open-access resources. In a world with scarce resources, his concern was that open-access goods, of common use,would end uprunning out if there were not a sociallyaccepted regulation for limitingthe use of and the access to them.

According to the thesis supported by Hardin, if men do notrestrict the individual freedom, they risk ending up like the inhabitants of Easter Island, because they would destroy the common goods on which the life of the human species depends.

The American ecologist analyzes the goods by considering the combinations of two couples of characteristics relating to their modalities of consumption: a) «rivalry» versus «nonrivalry» in the consumption; b) «excludability» versus «non-excludability» from the consumption. In a nutshell, the «common goods» fall into the case in which the good is rival (e.g. the cubic meters that John Doe draws from a lagoon cannot be used from other people),butnon-excludable (it may be impossible to keep a person from drawing water from the lagoon, even if he/she does not pay anything). Due to rivalry, and fearing the depletion, everyonetends to forestall the consumption 
of goods by other people and maximize his/her own consumption. Moreover, even if the amount available (supply) decreases and the price increases, the demand does not decline, because no one can be excluded. So, each individual is urged to consume goods until the moment in which the cumulative effect of individual consumption will correspond to the depletion of resources. The result is the «tragedy of the commons», i.e. the unavoidable tendency towards congestion and hyper-consumption and the consequent depletion of natural resources, if they are managed as «open-access» common goods.

It is interesting to notice that Hardin does not use the word «tragedy» to mean "ruin", "irreparable damage", "unfortunate outcome", but to describe from a social point of view a dilemmatic situation that recalls the«prisoner's dilemma», i.e. a situation for which no optimal solution exists as long as men accept the anthropological assumption based on which all the individuals behave according to the standard of the homo oeconomicus. In order to perpetuate the dilemma, people must therefore act in a rational, instrumental and selfish way and must not be able to reduce their consumption on the basis of voluntary agreements nor to respect the juridical regulations issued for this specific purpose ${ }^{5}$.

The mother, Elinor Ostrom, developed instead a prescriptive model -in some respects more specific - and acknowledged that the commons can be subjected to communitybased management by users, proposing amodel ofself-governance as an alternative to the public model. In other words, between public and private management common goods should be subjected to common management.

According to Ostrom, who was awarded the Nobel Prize for economics, the solution for the «tragedy of the commons» based on the self-organization of the community is perfectly possible. Of course, this perspective modifies in a substantial way the range of the economic institutions that the economists consider to be worthy of attention and makes it possible to downsize the rather dominant role that the free market has today. In fact, starting from the study of some cases of community-based management of irrigation systems in some communities of developing countries - but also cases of multilevel management of reservoirs in the USA, where common possession is effective - Ostrom has shown that it is possible to establish social rules and institutions for access to natural resources and avoid the «tragedy» through self-governance. The 
basic concept is to channel the energies of the organized civil society into the invention of new ways to manage common goods that comply with models of participative democracy ${ }^{6}$. In practical terms, the management model must be congruent with the nature of the good in question: if it is common, then also its management must be so ${ }^{7}$.

As a matter of fact, the «tragedy of the commons» suggested that privatization strategies should be adopted by the mainstream ideology, i.e. strategies for introducing private property rights in the place of common goods, in order to manage the effective excess demand compared to supply - through the variation of the price.

In this way, since people are compelled to pay prices that are higher than the marginal utilty of the good when the resource is running out, the neoliberal policies have obtained an automatic way to discriminate men depending on their willingness to pay a price on the market ${ }^{8}$. But what is neglectedis that the pricedoes not express the value of a good and that the discrepancy that arises between the price and the value of goods is so great that even the economists cannot find a solution. It has been noticed, in fact, that this problem is inherent in the very idea of the prices determined by the logic of profit, which is bound to produce through the free market - a huge social inequality ${ }^{9}$.

In the juridical sphere, these arguments led some scholars to seriously question the categories on which the social and political thinking of the modern Occident is based. Ugo Mattei expresses an interesting proposition that contemplates the demolishment of the traditional (juridical and non-juridical) categories: according to him, common goods cannot be seized if we do not free our minds from the most rooted conceptual frameworks through which we view reality. This proposition goes beyond the traditional juridical and political categorizations and questions classical dichotomies such as «to be» and «to have» or «subject» and «object». A common good must no be considered to be a mere object, a tangible part of the external world. It cannot be seized through the mechanistic and reductionistic logic typical of Illuminism, which sharply separates the subject from the object. In short, it cannot be attributed to the modern idea of goods. The common good exists in a «qualitative relationship». We do not«possess» a common good (an ecosystem, for example), but we «are» somewhat a part of the common good (we are a part of an urban and rural ecosystem). So, the separability between «to be» and «to have», subject 
and object, is called into question by a political theory that places common goods in the foreground. These goods can be defined as such thanks to the material contexts in which they become relevant and not because of their ontological, objective or mechanical characteristics ${ }^{10}$.

As a result, from a juridical and functional perspective, recognizing an entity as a common good means declaring its incompatibility with both the logic of public systems (characterized by the delegation to the government and its bureaucracy)and the logic of private systems typical of possessive individualism, whose main goal is to accumulate wealth and resources.

In a perspective of radical overturn of the traditional principles of the burgeois constitutionalism, it is necessary to find juridical solution «beyond» the traditional dichotomies State/market, public/private property. Common goods are the basis of an authentic participative democracy based on the individual responsibility and commitment to get long-term benefits for everyone.

While these doctrines have obtained no legislative validation so far, they have been partially accepted by Italian law. In fact, with respect to the juridical nature of the Valli da pesca della laguna veneta ${ }^{11}$ [fishing valleys of the Venetian lagoon], the Court of Cassation invited to view common goods «beyond a merely patrimonial and proprietary perspective», underlininga public and collectivistic functionality and purpose. After identifying the constitutional foundations of the collective use of public goods in Articles 2, 9, 42 of the Italian Constitution, the judges have asserted that discussing in terms of exclusive dichotomy between public and private goodsmeans identifying in part the mere ownership of goods, neglecting the fundamental aspect that they arecategorized according to the functions and the interests linked to them ${ }^{12}$.

In short, from abenicomunista ${ }^{13}$ perspective, this means studying and devising structures of participative and authentically democratic government which can attract the more motivated administrators, incentivize the pursuit of a transnational and transgenerational logic (e.g. the ecological one) and verify their actions throughthe universal exercise of the fundamental right to access ${ }^{14}$. The identification of common goods is reached «from the bottom», that is to say through activities, social conflicts and - above all - through the widespread perception that a certain good must meet colletive needs ${ }^{15}$. 


\section{SOME CONSIDERATIONS OF CONSTITUTIONAL ORDER}

Within the Italian doctrinal debate, severe criticism ${ }^{16}$ has been expressed against the above-mentioned theories.

For constitutional lawyers - it has been said with poetical irony -the scientific value of the juridical construction of common goods «ha la resistenza di un fiocco di neve fluttuato in casa dalla porta semiaperta» ${ }^{17}$. It has been said - in other words - that it is scientifically tenuous.

In fact, the juridical theories about common goods tend to overstepnot only the proprietary egotism as an elemental paradigm forprivate law, but also the State sovereignty as a necessary filter for the community to manage and enjoy resources ${ }^{18}$. On the one hand, it is thought that - in the course of time -the citizens have been dispossessed of the popular sovereignty by the institutions, which are stuck in a representative circuit all in all self-referential. On the other hand, heavy criticism is levelled at the big "Leviathan" of these days - the capitalist economy - that aims, through the accumulation of material wealth, at taking the possession of the State sovereignty and putting it in the "invisible" hands of the economic subjects that dominate the market ${ }^{19}$.

So, if on the one handthe benicomuniste theoriesdo not appear to be lacking foundation and discernment, because they have brought to light the «human idiocies» related to the plunder of nature $^{20}$ that the biological ecologists denounced time ago (besides the juridical artifices that the capitalistic production system has used to create a plutocratic society characterized by inequality), on the other hand they seem to be willing - maybe too easily - to get rid of both the constitutional function of the «public» dimensionand the responsibility coming from the egotism of «private» subjects.

In fact, from a juridical point of view, it is not easy to place within the constitutional system the thesis according to which the distinction between public and private - rather than their contraposition - should be overstepped, so that the dominant role can be played by the "common", i.e. a dimension that directly refers to the civil community as such and not toa public institution that represents the citizens. In fact, if one intends to adopt such perspective, one will encounter an enormous difficulty: the necessity to identify the reference community (a neighborhood?, a municipality? a region or the State? the whole humanity?), to establish its 
boundaries, its overall structure and the internal organization, besides the rules of inclusion and exclusion. One aspectis almost ineluctable: the contradiction between the tendencyto limit the extension of the community that participates in the management of common goods according to horizontal rather than top-down modules - in compliance with the model of participative democracy - and the necessity to effectively guarantee the universal and equal right to enjoy the goods that - precisely as common goods -afford the exercise of the fundamental rights and the free development of human individuals ${ }^{21}$.

Since both the public and the private dimensions are fundamental for democracy,the constitutional system must rather have the possibility to limit both of them, because it is aware that if no confidence is placed in any of them, they both can have the power to violate human rights ${ }^{22}$.

If so, common goods risk being a magic flute towards the nothing, if they are abstractly thought to play the role of almighty and all-inclusive salvatores mundi. They can have a juridical importance only if they are firmly built on the "subversive" basesthat exist but have not yet been implemented by the republican Constitution: in particular, by carrying out the project of social democracy contemplated by Articles 2 and 3, paragraph 2 of the Italian constitution, whose explicit purpose is to reach the personal and social emancipation of the whole community.

So that the «common» goodcan bebeyond, in the sense that it can develop the vision of a new world. But, according to the Constitution ${ }^{23}$ this can realistically happen from and in the public sphere.

It is not a coincidence that the "new" constitutionalisms focused on the "common" sphere- like the ones that have been historicized in the constitutions of Ecuador and Bolivia have assimilated (i.e. positivized), a vision of the world that considerably differs from the anthropocentric vision of the European and North American constitutionalisms.

In fact, the Andeannuevo constitucionalismo deals with the "dilemmas" related to the "externalities" caused by the collective choicesfrom a constitutional point of view and does not consider the problems related to nature and sustainable development to be mere questions of political "discretion" within an unchanged frameworkof rules regarding authority-freedom. In opposition to the liberal-democratic perspective of the Occident, which focuses on the 
individual, the perspective of nuevo constitucionalismo is focused on ecology, so that society and nature are given constitutional roles that are subjective and active. As a result, a citizen can for example apply for a recurso de amparoagainst the administrationto defend the "rights of nature", since its "common" resources are fundamental for the life and the wellbeing of everybody ${ }^{24}$.

In other words, vis-à-vis an ecosystem that is being destroyed (by the conflict between limitless economic growthand limited world) andwithin such constitutional regulations, the famous "trust dilemma" described by Rousseau is not focused on the prey, but rather on the survival/extinction of the hunter himself. With the awareness thatthe"preference" (the hunter appropriates the natural goods) has become "tragic"compared with the "choice" (the hunter decides the good he wants to hunt), men are explicitly considered to be a part of nature by the Constitution, rather than its almighty manipulators.

It has already been $\operatorname{said}^{25}$ that this became theConstituent Dilemma of the $21^{\text {st }}$ century, how and whatto decideabout this "tragedy".

That is why, compared to the "classical" categorizations of the European and North American democratic systems, these models do not fulfil the anthropomorphic requirements of representativeness and freedom that define democracyas exclusively human responsiveness. Between democracy and nature, between negotiable or deliberative choices and coercion in the name of the "pro natura", the latter must prevail, not only to meet "non-balanceable" needs, but above all to pull the constitutional regulations in a different, non-negotiable direction.

Otherwise - this seems to be the main threatthat the Andean constitutionalism intends to remedy- the economic benefits and rights will always (or almost)prevail over all the others. Therefore - it also seems to express - in the "name" of nature,the power cannot be fully democratic, because it would fall into the self-destructive «human stupidity» above denounced from biologists and ecologists.

Anyway,this is the issuethat needs to be highlighted the most: as long as these questions are not perceived and metabolized by the juridical culture of the Occident through a brand-new constituent process, thesesand theories like the ones about common goods are unlikely to become concretely functional and juridically valid. 
One thing is certain: in that South of theWorldthat is being "decolonized" from the representations of the colonial reason of the Occident,these themes acquire new postulates and paradigms about the future that must be known and compared to ours, in order to really identify a "new statute" of citizens ${ }^{26}$.

\section{OVERVIEW ON THE RIGHT TO ADEQUATE NUTRITION}

At the international level, a first juridical formulation aimed at safeguarding the right to adequate nutrition can be found in Article 25 of the Universal Declaration of Human Rights proclaimed by the United Nations General Assembly in Paris on 10 December 1948. The purpose of this article is topositivize the wider right to an adequate standard of living ${ }^{27}$, stating in the first paragraph that: «everyone has the right to a standard of living adequate for the health and wellbeing of himself and of his family, including food, clothing, housing and medical care and necessary social services, and the right to security in the event of unemployment, sickness, disability, widowhood, old age or other lack of livelihood in circumstances beyond his control».

The same universalistic safeguard of the right to adequate nutrition is offered by Article 11 of the International Convenant on Economic, Social and Cultural rights, a multilateral treaty adopted on 16 December 1966 within the framework of the UN and in force from the 23 March 1976.

Just like Article 25 of the Declaration, the first paragraph of Article 11 demands that the Nations recognize «the right of everyone to an adequate standard of living for himself and his family» and explicitly defines «adequate nutrition» in terms ofa material condition that must be guaranteed to everybody, since it is essential for life.

Within national law, on the contrary, the general situation seems to be the following: no fundamental right to adequate nutrition is expressly provided by the regulations of the Italian Constitution. For now, it is therefore a fundamental right with an external origin, which - as we will see - has led the national jurisprudence to implicitly declare it in its verdicts.

In fact, unlike the Bolivian Constitution - whose Article 20 establishes that «each individual has the universal and equal right to access to the service of drinking water [...]. Access to water is a human right and cannot be subjected to concession and privatization» - the management of 
water services in Italy has risked being entrusted to private citizens ${ }^{28}$. Moreover - this is the whole point - access to food is almost entirely ${ }^{29}$ at the mercy of the social forces that are freely deployed on the free market, even when it comes to the bare minimum of subsistence.

Since - at the constitutional level- the regulations of the Italian Republic do not have (unlike other modern forms of constitutionalism) the explicit «obligation to guarantee [...] healthy and adequate nutrition, sufficient for the whole population» (still Article 16 of the Bolivian Constitution), we could say that food has easily become accessible on the markets for people who - thanks to a sufficient salary to buy it - have the possibility to own foodiure privatorum ${ }^{30}$.

This means that our Constitution lacks a public service of food assistance aimed at ensuring the poor the possibility to be freed from the inconvenience of «hunger» ${ }^{31}$.

These conditions have made it possible for the right to access to nutrition to be recognized as fundamental by the judges through inter-constitutional interpretations ${ }^{32}$. This means that they have had - in the interpretative/applicative phase and formally referring only to national law - to give more sense to the principles of our Constitution by drawing further regulatory meanings - to attribute to the preexisting ${ }^{33}$ constitutional legality - from the outside (i.e. from the rights and the principles contained in supranational documents).

\section{FOOD AND MARKET}

From the assumptions crystallized in the agreements of the World Trade Organization $^{34}$ (WTO)to the constitutional rights of the single nations of the European and North American Occident,food is considered to be a mere "good". Any other dimension is neglected, especially the one according to which food, together with water, is a basic resource for the populations' life.

To be convinced of this, it is sufficient to read Article 5 ofRegulation (EC) no. $178 / 2002$. When it comes to defining the purposes of food law, the article explicitly highlights how important the «safeguard of the consumers' benefits» and the «free movementof food and animal feed produced and put on the marketwithin the community» are. Moreover, if we read this article together with the previous Article 2 (which provides a definition of «food»), we come to the conclusion that EU food law mainly - if not exclusively - deals with the «right of nutrition» (i.e.

Right to food and "tragedy" of the commons 
with the rules of production, processing, distribution, commercialization and movement of food, addressed to «consumers»), rather than with the «right tothe nutrition» of the population, i.e. the individuals' right to feed themselves in an adequate way, in order to live in a respectable way.

It seems, then, that EU law does not take care of regulating the vital «access» to food in the European territory. Instead, it only deals with the aspects related to its «commodification», thus influencing the evolutive interpretation of the Member States'Constitutions and ultimately causing - through its tendential primauté - slow and silent transformations from social into neoliberal democracies.

The dominant principles of the free market and «privante» ${ }^{35}$ property - which deprives people also of consumer goods - have a considerable impact on the possible meanings that the regulations of the republican Constitution can or cannot take on in the practical application $^{36}$.

For the purpose of this work, it is sufficient to consider the blows that EU law has dealt to Article 42, paragraph 2 of theConstitution, in the point in which it is stated that the recognition and the guarantee of private property given by law must have «the aim ofensuring its social function and of making it accessible for everybody».

In fact, the competition in the free market - that is the fair of the so-called "best" cannot ensure the "food-goods" to everybody alone, since the word«everybody» itself does not make it possible to deny access to these goods to certain categories of individuals.

The article can be given another correct interpretation, in line with the whole system of social democracy described by the Constitution, according to which the legislator - in order to ensure the collective enjoyment at least of the goods essential for life (such as food) - must restrict thefreedom "of trade", even by preventing private citizens ${ }^{37}$ to claim any right to property, so that the Republic can effectively guarantee «essential levels for the performances regarding civil and social rights» ${ }^{38}$.

It has been said, in this respect, that - if the laws regarding property are given an interpretation inspired by Article 42 of the Constitution seen as a foundation for a right to property aimed at ensuring the social function of goods, rather than an absolute subjective right - it 
would be possible to assert that if the social function that allows law to guarantee the right to property is lacking, then also the proprietary title of which goods are the object ${ }^{39}$ will be lacking.

However, it is clear that within the current structure of the European juridical/economic system, this type of guarantee seems to be inexorably condemned - if not disregarded - to be slowly buried in the juridic cemetery of desuetude.

The right to adequate food ${ }^{40}$ is then no longer perceived as a question that exclusively regards the poor and needy people of the world and is more and more seen as an entitlement that concerns the human condition as a whole, at any latitude.

In a global world ruled by markets that are more and more independent of the sovereignty of the single Nations ${ }^{41}$, it is unavoidable that also the phenomenon of poverty increases its dynamism, affecting entire segments of population and reducing them to misery with incredible speed compared to the past.It has been noticed that the presence of the poor in the common spaces of the everyday life of rich countries and cities has increased again: they beg, sleep on the streets, rummage through rubbish and queue up at the soup kitchens ${ }^{42}$.

It is not a coincidence that, in 2011, even the big global food companiessupported the PVOs(private voluntary organizations) and the international organizations ${ }^{43}$ in demanding that G20 did something for the «global food security».

Although food is a complex sociocultural ${ }^{44}$ element, a «basic elementfor citizens» and, as such, a «precondition of the democracy itself ${ }^{45}$, today one must necessarily turn to the market to adequately feed oneself, even with no salary. Which clearly represents a paralogism, a nonsense that collides with the Constitution, which states that the legislator must establish suitable plans and controls, so that the free economic activity «can be aimed at and coordinated for social purposes» in order not to «cause damage to safety, freedom and human dignity» (Article 41 of the Constitution).

As it has been said at the beginning, Italian law does not include effective juridical remedies that ensure the needy food assistance (which is provided by Articles 3 - paragraph 2 and 38 of the Constitution). In this regard, an effort has been made by introducing the social card which, however, has turned out to be, all in all, an unsuccessful measure ${ }^{46}$, due to the political 
and administrative inefficiency and to the lack of funds of the local institutions caused by the European Austerity measures.

Without considering that the «state of poverty» is not ascribable to a mere economic question: it is oftend neglected that it regards the juridical possibility of «access to the means of subsistence» $^{47}$.

Anyway, in Italy over 3 millionsfamiliesdo not have adequate food. The income of the poor population - unlike the rich one - has further decreased due to the economic crisis: $18 \%$ of the Italians aged 15 to 64yearsskip meals and $40 \%$ have reduced the overall consumption $^{48}$.

Indeed, precisely with respect to the social cardintroduced in 2008, the Constitutional Court - through a systematic and evolutive interpretation of some regulations (Articles 2, 3 second paragraph - and 38 of the Constitution), has removed foodfrom the sovereignty of the free market and has recognized the legitimacy of «a State intervention that includes also the prevision of the proper and prompt provision of a certain providences ${ }^{49}$ in favour of the needy.

In this way, at least, the minimum juridical conditions of our system have been legitimized, so that a fundamental right ${ }^{50}$ - namely the right to adequate nutrition - can be safeguarded and put into effect through innovative public interventions ${ }^{51}$.

After all, in an interventionist nation oriented toward society - such as Italy - forms of public intervention in the economy, aimed at directing and coordinating the public and private economic activityfor social purposesare constitutionally imposed by both the social emancipation policy described in the 2nd paragraphof Article 3 of the Constitution(and recalled in the $2^{\text {nd }}$ paragraph of Article 4, in the point that refers to the «material progress» of society), and the constitutional recognition of social rights ${ }^{52}$. If these regulations should turn out to be retrogressive compared to other sources, the balance underlying the social - albeit not easy democracy of the Founding Fathers ${ }^{53}$ could be upset. 


\section{FOOD AND COMMON GOODS}

At this point, after providing the outlines of the doctrines relating to common goodsand the right to food, a question arises: is it possible tosee food asa common good to rescue from the "tragedy"?

The answer is not easy, but I will try hereafter -albeit concisely - to illustrate some arguments against this possibility.

At the economic level, the fact that the Occidental contemporary societies are based on theGrundnormof the free market makes food a good that is "rival", but mostly "excludable" (unlike what is stated by Hardin) from the logic of the prices set by the capitalist production processes.

Except the marginal cases of self-sustenance of property owners, who -as such have the possibility to consume and find some food in the plots of land they own (of course not all, which means that nutrition is inadequate), food is available on the markets and is moreover processed by other economic actors acting in the same economical and speculative context. Since food is subjected to the rules of demand and supply,people with an insufficient income cannothave access to it, because they cannot pay its price.

A different argument applies toanother fundamental good: drinking water.

Since the economic system cannot prevent people from acquiring water to feed themselves freely (from a public fountain, for example) - although this good has been the object of attempts of commodification and privatization - in this case the theory of common goods has had the possibility to take root and find expression. In fact, as it has been said above, the political slogan "water common good" led the Italians, in 2011, to side againstthe privatizationof «public servicesof economic relevance» (including water) through the referendum that took place on the $12^{\text {th }}$ and the $13^{\text {th }}$ June of the same year. From an economic point of view, unlike food, water is partially "non-excludable", besides being "rival", which is perfectly in line with the economic theory of common goods.

At the juridical level, things do not change that much.As it has been underlined, going "beyond" the public and the private dimensionsnot only means disregarding the 
socioculturalprinciples of the Occident, which religiously worships the free marketin a fundamentalistic way, but also collides with the republican Constitution and its principles.

In fact, beyond the dichotomy public/private, there is no offshoot of the republican Constitution that can give firm guarantees to citizens and residents, which juridically risk falling into the nothing and being deprived of a positive protection.Moreover, the underestimation of the political and cultural context (which legitimizes the system ${ }^{54}$ ) and the positive data (the formal Constitution that does not know common goods) may turn out to be a lethal mix for the structure of constitutional democracy. In fact, the Constitution has been calibrated in order to create balance between the public and the private spheres and hold them together, rather than to go beyond them. It is not about taking a reactionary position towards the doctrines of common goods or being traditionalists, obtuse and closed to new ways of seeing the juridical relationships. On the contrary, it is about being aware of the fact that the historic and material conditions to fully understand the good that lies in common goods are not ripe. The biggest risk is to lose sight of the unexpressed potentialities of the "public" dimension in favour of a "common" dimension, which - since it is not clearly defined in its juridical traits - risks strengthening even more the benefits of the few "private" citizens that already possess half of the global wealth ${ }^{55}$.

Let us focus again on the right to food, which is undoubtedly a fundamental right. The positive aspect does not lie in the fact that it is "common", but in the fact that everybody can have access to its enjoyment, so that the whole community has the possibility to live a respectable life, free from hunger. Therefore, in order to be constitutionally valid, the adjective "common" must be read as synonym with "everybody", according to what is said by Article 42 of the Constitution with respect to the individuals' material accessibility to those that, like it or not, are de iure condito the «terrible» rights of public or private owners.

Therefore, a higher scientific value can be attributed to the doctrine that, rather than a common good, considers food to be an«asset» when it goes beyond one's possibility to pay for the minimum amount of food needed for survival and a «social good» when it can guarantee the fundamental right to human subsistence ${ }^{56}$. In other words, food can be considered to be a good subjected to free exchange on the market (thus becoming subjected to property rights) when only the individuals who have a certain income can have access to that good. On the contrary, if the 
economic condition cannot even guarantee the subsistence, food unavoidably turns into a social good, i.e. a good that embodies a social right that, as such, compels the institutions of the Republicto remove any obstacle that hinders de facto the enjoyment of the fundamental right to access to this good (Article 3, paragraph 2 of the Constitution).

This leads to the conclusion that if we really want to definitively resolve the issue of access to food, we must deal with it from a different perspective: we must no longer place it exclusively within the context of the economic principles underlying the process of production and consumption of food.

As Karl Marx taught us, food is a product and an object of consumption at the same time ${ }^{57}$. Agriculture as the cultivation of the ager and farms as functional instruments ${ }^{58}$ have enclosed the agricultural industry in a frame of economic factors and food law in a frame of rules concerning relationships that do not relate to it. It is not a coincidence that food policies are mostly subjected to agro-economic regulations and that - in jurisprudence - they are a matter of agricultural law. The clearest evidence is represented by the regulations issued by European law so far. The "economic" figures of "producer" and "consumer" are the most relevant "legal entities"for the law of the Old Continent. As seen, all European law concerns the series of production and consumption processes aimed at meeting the needs of trade ${ }^{59}$.

For the European food policies and for the resulting law, food safety is a priority, in the sense that the «healthiness of the agricultural produce» and the consumers' safeguard represent the basic goals of the European common market ${ }^{60}$. The principle of the Lisbon Treaty regardingthe «social market economy» is still an empty formula; just as food policies do not consider the civis europaeus to be a "human being" with his vital needs; the political and juridical attention towards food and nutrition as a source of individual rights or as social goods aimed at ensuring people their fundamental rights is today marginal.

Right to food and "tragedy" of the commons 


\section{WHAT CAN BE DONE TO AVOID THE “TRAGEDY"? PARADOXICAL CONCLUSION}

Once food is deservedly placed among the fundamental rights, another strange legal regulation must be taken into account, which can be implicitly inferred from the system: a law that invites the fast, just like Occidental doctors often write in their prescriptions.

In fact, if one simply takes note of what is provided by the formal juridical system, it isunavoidable to realize that Italian law is clearly unreasonable, because it provides a public service that guarantees access only to water, while food, albeit essential for life, is left at the mercy of the forces of the free market.

The problem arises especially when these disparities of safeguard affect indigent people - not protected by the State - who claim the right tonutrition because it is fundamental right, and not because they are mere "consumers" who have access to the rights of nutrition. The issue is far from being secondary and shifts the attention from the level of "lex mercatoria" to the level of "lex fundamentalis" - i.e. a «supra-constitutional» level - because ultimately it is all about dealing with rules and principles that must not only affect the State incomes, but also the dignity of human beings ${ }^{61}$.

Nowadays, the challenge to food seems more than ever to be a political challenge ${ }^{62}$. And, like all the political questions that are closely related to the fundamental rights and principles, it is a challenge that - due to its "ecumenical" value - has above all a constitutional significance $^{63}$. Somehow, the challenge to the right to «adequate» nutrition seems to envisage a different worldview according to which the forward-looking intelligence of men and the institutional activities (at any level, but above all "from the bottom") cooperate to build new organizational models different from the current ones.

In the light of what has been said, it seems necessary to clarify another point: there is the need to experiment political and institutional models able to upset the current individualist and anthropocentric worldview and in favour of social policies of solidarity that can coexist in harmony with every thing around us or, to be more precise, with the «environment» seen as natural heritage that includes also men ${ }^{64}$, in front of whom «terrible» rights and limitless economic powers must surrender, if necessary. 
It is not about sharing peaceable perspectives nor about believing in a world where it is suddenly possible to live in a new phantomatic state of nature characterized by the total absence of social conflict. Such perspective would be unhistorical and naive.

More simply, it is about thinking that in a period of economical, financial, environmental and structural crisis like the one that is affecting the current society - in which poverty is threatening a higher and higher number of citizens and families of the so-called middle class, which is about to die out - dealing with «food availability», with its «adequacy» and - above all and from a constitutional perspective - with its «economic accessibility» can only turn out to be useful to reconsider the traditional competences and the main functions of the public administrations that are close to the population. Therefore, "inside" the public sphere, in support of the social democracy contemplated by the Constitution, rather than "beyond", as the benicomuniste doctrines want.

As I have explained in other works of mine ${ }^{65}$, it has been explained that, in order to reduce the macroscopic disparity of approach towards two rights (to water and to food) that are equally fundamental, it would be appropriate to introduce into the system a permanent public service of food assistance aimed at ensuring adequate food to all the indigents legally residing in the territory of the Republic. In a nutshell, starting "from the bottom", through a minimum contribution from the residing population with an income above a certain threshold, it is possible to create in the municipalities a local service: a public food service (through food stamps, family allowances to buy food, agreements with restaurants, supermarkets, etc...), in order not to weigh on the already precarious economic situation of the local institutions.

Consider, for example, a municipality with 50,000 taxpayers with an income above a certain threshold. If each taxpayer should donate only 50 cents per day to support the local service of food assistance, a monthly amount of 750,000 Euros would be available for the residents with an income that does not guarantee access to adequate food. In this way, the municipality would have the possibility to always give 5,000 residents 150 Euros per month to be spent exclusively for nutrition.

Regardless of the numerical data, which require anyway a detailed and constant study on the poverty rates of each municipality, this possible perspective «of solidarity» oriented 
towards the Constitution (Articles 2 and 53) ${ }^{66}$ could represent - better if combined with innovative measures against food waste ${ }^{67}$ - an effective political action to publicly implement values and principles that, so far, the ruling class has all in all left in the orbit of what is juridically irrelevant ${ }^{68}$.

Ultimately, at the constitutional level, «reasonableness» - that, as it has been effectively said, represents a true «architectural principle of the system» ${ }^{69}$ - gives way to positive «irrationality» if the legislator does nothing to balance the juridical safeguard of two goods that it has been said again and again - both embody the same funamental right to nutrition ${ }^{70}$.

Of course, since these goods have different qualitative and quantitative features by nature, the economy can diversify their value (of exchange) depending on the production methods which a certain State allows the economic entities to adopt.

However, from the perspective of constitutional law and, in particular, of the safeguard of fundamental rights, no doubt that no distinction can be made between water and food. Otherwise, as it has been asserted, law would be completely subordinated to the economy, which would be the only reasonable «structure» ${ }^{71}$ on which every other social phenomenon depends (not onlylaw, but also politics, religion, art, philosophy, etc...).

The same thing would happen if an attempt were done to resolve the problem by searching the fine-mesh net of the formal juridical logic to find a possible «scientific value freedom» ${ }^{72}$. Which, if used to give sense to the fundamental right to adequate nutrition, leads to an aristotelian syllogism: all men must eat to live (major premise); food and water can be ingested (minor premise); food and water are vital for men (conclusion).

So, it is clear that the constitutional system cannot permit indiscriminate «exclusions» from access to food, which - on par with access to water - must be «universal», since also food is fundamental for life.

Since no one has the right to behave as though he was the last human being on the Earth and no one has the right to appropriate and deny the others access to collective goods ${ }^{73}$, once food is (re)considered by law to be a fundamental sociocultural good, the «rivalry» for the acquisition of food on the market needs to be downsized proportionally to its guarantee for those who cannot afford it ${ }^{74}$. 
If no service of public assistance ensures the poor also «adequate food», the juridical paradox is an unavoidable conclusion: according to national law, one could legally and legitimately assert that it is possible to live only on water - with no food -in an «adequate» way.

\section{NOTES}

1 The committee for amending the regulations of the Civil Code with regard to Public Goods (called "Rodotà" from the name of its chairman),was formed in 2007 by the Prodi government and the Minister of Justice Mastella, with the purpose of defining a systematic regulatory framework for measures of privatization aimed at lightening the burden of the public debt. In particular, the Committee was set up at the Ministry of Justice by decree of the Minister in June $21^{\text {st }} 2007$ and accomplished its work by drawing up a draft law that delegated to the government the power of amending the Chapter II, the Title I of the Book III of the Civil Code, as well as other parts of the same book linked to it. Unfortunately, as it is known, no discussion has been held about this draft law in the institutional framework.

2 See Article 1, section 3, letter c)of the Proposal of Regulation.

3 See, at least, the attempt of classification made by CerulliIrelli and De Lucia, 2014, p. 6 et seqq.

4 The studies carried out by Rodotà seem to be particularly focused on this aspect, 2013, p. 459 et seqq.

$5 \quad$ See Hardin (1968), p. 1243-1248.

6 See Lucarelli, 2013 - p. 45 et seqq. - with respect to the forms that the participative democracy in the management of common goods can assume. See also Marella, 2012, p. 24, who recognizes the «collective and/or participative management» as a decisive element of a possible juridical statute of common goods.

7 For more detailed studies in this regard, see Ostrom (1990); Ostrom (1998), p. 1-22

8 In this regard, see Sacconi, 2015, p. 175 et seqq.

9 See Patel, 2009.

10 In this sense Mattei, 2012, p. 52-53.

11 The dispute was started because some private farmers claimed the right to own the bodies of water situated within the lagoon, where intensive fish farming is carried out. The State, which was the other party, laid claim to the ownership of these areas. The Supreme Court established that the lagoon was an area of public property.

12 Civil Cassation, United Sections, no. 3665 of the 14th February 2011. 
I.e. the perspective of the Italian advocates for the juridical theses on common goods

See Mattei, 2012, p. 60-61.

Lucarelli, 2013, p. 66.

See the caustic counterarguments of Vitale, 2013.

di Plinio, 2015, p. 189.

On the problems related to food sovereignty, Jannarelli, 2011, p. 299-325.

See Nivarra, 2012, especially p. 85 et seqq.

See De Lucia, 2013, p. 93-112; Sanchez (2010), p. 61-75.

D’Andrea, 2015, p. 9-10.

In this sense Fioravanti, 2014, p. 7, and p. 44 et. seqq.

This is the thought of Algostino, 2013, p. 28-29.

In this respect, see Baldin and Zago, 2014.See also Carducci, 2014, p. 138-151. With regard to the same topic and from his "benicomunista" perspective, Mattei, 2012, p.22, notices that the new Bolivian Constitution, together with the Ecuadorian one, is the juridical model that deals with the concept of common goods in the most advanced way available, should the humanity intend - after putting aside the Occidental arrogance - to revise its development model.

See Linebaugh, 2008.

In this respect, see the reflections of Cassano, 2004.

In this regard, see Eide, 2001, 133 et seqq.

As the Italians know, ex Article 75 of the Constitution, that is to say through the abrogative referendum of 12 and 13 June 2011, they have been in favour of the abrogation of Article 23 bisof the Decree-Law no. $112 / 2008$, i.e. the abrogation of the therein contained regulations concerning the privatization of public services of economic relevance, including the management of water.In this regard see Staiano, 2011, p.21; and, ultimately, Chirulli, 2015.

"Almost", because even if the problem of hunger has not been resolved, a few local services are taking hold in several municipalities of the Republic, including urban vegetal gardens (in different varieties, such as didactic, social and associative gardens), different types of soup kitchens,local markets, etc...

As it can be inferred, the attention is shifted - ex Article 42 of the Constitution - to the problems concerning the «social function» of ownership, especially the ones relating to its «accessibility for everyone». With respect to the «constitutional system of ownership», see Rodotà, 2013, p. 273-421.

Unfortunately, law often tends to distance this word from its real meaning, using instead expressions such as "undernourishment", "malnutrition", "food uncertainty" to talk about a problem - the vital lack of food - that still afflicts millions of people. In this regard, Caparròs, 2015, p. 15 et seqq. 
As I have better defined and explained in other works of mine, of which you can see, if you wish, Gusmai, 2015a, p. 47 et seqq.

With respect to the inter-systemic and inter-constitutional character of Italian law, determined by its openness towards external regulations, see the recent considerations of Ruggeri, 2015a.

See the Marrakesh Agreement establishing the WTO, signed on 15 April 1994, which includes the Agreement on Agriculture.

That is, in Italian, private property that "excludes", "deprives" someone of something. This suggestive expression is used by Mattei, 2014.

The Italian Constitution is the product of different and opposing political forces. That is why regardless of the influence of EU law - it is full of «antinomies and conflicts» that can be also found in its second part, i.e. the so-called «organizational» part. This is what has been noticed by Mortati, 1962 , p. 222 et seqq.

See Rodotà, 2013, p. 387.

As provided by Article 117, paragraph 2, letter m), of the Italian Constitution. In this regard, see Ruggeri, 2015b, p. 541 et seqq.

Lucarelli, 2015, p. 117.

In this respect, please allow for references to Gusmai, 2015b.

...to the point that the doctrine has recently talked about «absence of legislation» and about «law with no author» within the global dimension of law. Ferrarese, 2012, p. 54 et seqq. Other authors have instead a contrary opinion. Among them and above all, see Luciani, 2012, p. 3, who asserts instead that «Nations still play a central role in the supranational scenario».

Saraceno, 2015, p. 9.

In this regard, see De Schutter, 2013.

This aspect has been stressed by the President of the Republic himself, during his speech at the closing ceremony of Expo 2015 (31st October). In fact, he underlined that «the social and cultural importance of food policies is crucial and their value must be passed down through a serious educational commitment». See Mattarella, 2015. Ultimately, Ghiazza, 2015 curated an interesting collection of articles about the relationship of food with literature, cinema, linguistic structures, semiotic and psychological implications.

To use the words of Rodotà, 2013, p. 486.

However, considerable criticism has been made about the disappointing empirical data showing that the social card(a card to purchase essential goods, aimed at boosting the income of the needy)introduced by the Labour Law Decree of 10 January 2013 (published in the O.J. no. 102 of 3 May 2013), not only has been refinanced, but also reinforced and strengthened by some regulations that are currently being examined by the government. Therefore, it is not possible, now, to make further evaluations.

In this regard, see Cacciari, 2014, p. 69. 
Saraceno, 2015, p.98.

This is what has been decided by the Italian Constitutional Court with the sentence no. 10 of 2010 ("In law" section, point 6.4). Through the debate about the regulation that introduced the «social card» in Italy for the first time, (Article 81 of Decree Law no. 112 of 2008), the Court seems through this sentence - to have explicitly recognized the right to nutrition as both a «fundamental right» and a «social right», based on Articles 2, 3- second paragraph - and 38 of the Constitution.

The matter concerning the actualization of fundamental rights is dealt with in detail by Baldini, 2015 .

This is what many economists hope, including Mazzucato, 2014.

Colapietro and Ruotolo, 2015, p. 634.

With respect to the concept of «social democracy», seed'Albergo, 2004, p. 161 et seqq.

Mattei, 2012, p. XIV-XV, acknowledges in his introduction that, since common goods are loaded with political values, their compatibility with the common ideal must not be taken for granted.

According to the data provided by Oxfam (updated to January 2016), the situation is nothing short of embarrassing: only 62 people possess the half of the global wealth. The data can be consulted at this link: http:/ / wnw.oxfamitalia.org/eventi/sfida-lingiustizia-di-basta-ai-paradisi-fiscali.

SeeFerrajoli, 2012, p. 599 et seqq.

Marx, 2012, p. 44.

See Segré, 2011.

Ferrari and Izzo, 2012, p. 9.

SeeGabdin, 2011, p. 243 et seqq.

Human dignity is defined a «supra-constitutional» value by Ruggeri and Spadaro, 1991, p. 343 et seqq.

Although on the basis of different reasons, the same opinion is expressed by De Castro, 2015, p. 81.

The closeness of constitutional law to the political dimension has been recently underlined by the Italian Constitutional lawyersZagrebelsky and Marcenò, 2012,p. 65.

In this respect, Ostrom, 2009, p. 419 et seqq.

See Gusmai, 2015b p. 13 et seqq.

It is well know that Article 2 of the Italian Constitution - in a dialectical relationship with the «inviolable rights of man» - expects that «the fundamental duties of political, economic and social solidarity be fulfilled». By fulfilling the duty to contribute (Article 53 of the Constitution) to public expenditure for a public local service easy to manage and control (e.g. through the online publication of both the balance sheet of the institution that provides the service and the incomes of users), the population could allow local institutions to withdraw a derisory amount of money from the medium-high incomes and redistribute wealth in favour of the weakest subjects who have not access to adequate nutrition. 
Think of the recent French regulation against food waist that, inter alia, compels supermarkets to give unsold food to the needy. In fact, according to FAO the amount of food that ends up in the garbage accounts for over $35 \%$ of the global production, for a cost of about 1 trillion dollars per year. While these words are being written, also the Italian legislator is discussing a draft law against food waste (presented by the MPs Chiara Gadda and Massimo Fiorio).

It is not a coincidence that in the section about the "Right to food" of the most prestigious encyclopedia of international law (Max Planck Encyclopedia of Public International Law), it can be read thatthe right to food is one of the less respected human rights, as shown by the data about global malnutrition and hunger. SeeMechlem (2008).

D’Andrea, 2005, p. 203 et seqq.

70 With respect to the possible «arbitrariness of legislation» and the terminological distinction between the «irrationality», «unreasonableness» and «injustice» of juridical choices, see once againZagrebelsky and Marcenò, 2012, p.195 et seqq.

71 This is a reference to Marx, who considers law to be a «super-structural» manifestation of the mode of production, since its character is not autonomous and historically determined. According to his theses, law is not something beyond the classes that are struggling, something that impartially judges the actions of social actors: on the contrary, it is the reflection of certain social relationships (which it ratifies and legitimizes) as well a way through which the ruling class dominates the other classes. In this respect, see the considerations of Bobbio, 1997, p.153-166.

72 This is a clear reference to the famous "methodological" essay by Weber, 1917.

Cacciari, 2014, p. 81.

74 The fact that the laws produced by the State (and by the consequent activities of public institutions) often create a high level of social inequality has been recently underlined by Stiglitz, 2012 .

\section{REFERENCE LIST}

ALGOSTINO, A. Riflessioni sui beni comunitrail "pubblico" e la Costituzione. Costituzionalismo..it: 3 pp 28-29, 2013. <http://www.costituzionalismo.it>. Accessed: 25 jan. 2016

BALDIN, S.; ZAGO, M. Lesfide della sostenibilità. Il buen vivirandino dalla prospettiva europea. Bologna: Filodiritto, 2014.

BALDINI, V. La concretizzarione dei diritti fondamentali.Tralimiti del diritto positivo e sviluppi della giurisprudenza costiturionale e di merito. Napoli: Editorial e Scientifica, 2015.

BOBBIO, N. Né con Marx né contro Marx. Roma: Editori Riuniti, 1997, p. 153-166.

CACCIARI, P. Vie di fuga. Crisi, Beni comuni, lavoro e democrazia nella prospettiva della decrescita. Napoli: Marotta \& Cafiero editori, 2014. 
CAPARRÒS, M. La fame. Torino: Einaudi, 2015.

CARDUCCI, M. Per un costituzionalismo "Handy" nell'epoca dei mutamenti costituzionali incostituzionali. Alternative per ilsocialismo, 32:138-151, 2014.

CASSANO, F. Homo civicus. La ragionevole folia dei beni comuni. Bari: Dedalo, 2004.

CERUllitrelli, V; DE LUCIA, L. Benicomuni e diritticollettivi. Politica del diritto, 1: 3-36, 2014.

CHIRULLI, P. I servizi pubblici locali e il servizio idrico integrato tra legislatore, Corte costituzionale e (presunta) "volontà" referendaria. Federalismi. it: Rivista di Diritto Pubblico italiano, comparato, europeo, 2015, 7:1-39. <http://www.federalismi.it Accessed>. 25 Jan 2016

COLAPIETRO, C. M. Ruotolo. Diritti e libertà. In: MODUGNO, F (ed). Torino: Diritto Pubblico, 2015.

D’ALBERGO, S. Diritto e Stato Tra Scienz̧a Giuridica e marxismo. Roma: Sandro Teti Editore, 2004, 161 et seqq.

D’ANDREA, L. Ragionevolezż e legittimazione del sistema. Milano: Giuffrè, 2005.

D'ANDREA, L. I beni comuni nella prospettiva costituzionale: note introduttive. Rivista AIC, 3:9-10, 2015.

DE CASTRO, P. Cibo. La sfidaglobale. Roma: Donzelli Editore, 2015.

DE LUCIA, V. Towards an Ecological Philosophy of Law: a Comparative Discussion. J Hum Rights and the Environment, 2: 93-112, 2013.

DE SCHUTTER, O. Rapport intérimaire du Rapporteur spécialsur le droit à l'alimentation. A/68/288, 7, p 7-8, August 2013.

DIPLINIO, G. Ambiente. In: SOMAINI, E. (ed) I beni comuni oltre il comune. Torino: IBL Libri, 2015.

EIDE, A. The Right to an Adequate Standard of Living Including the Right to Food. In: EIDE, A.; KRAUSE, C.; ROSAS, A. (eds) Economic, Social and Cultural Rights. 2nd edn. Boston; London: Brill; Dordrecht, 2001, 133 et seqq.

FERRAJOLI, L. Principia iuris. eoria del diritto e della democrazia. Teoria della democrazia. vol II. RomaBari: Laterza, 2012, 599 et seqq.

FERRARESE, M. R. Prima lezione di diritto globale. Roma-Bari: Laterza, 2012, 54 et seqq.

FERRARI, M.; IZZO, U. Diritto alimentare comparato. Bologna: Il Mulino, 2012. 
FIORAVANTI, M. Pubblico e privato. I principi fondamentali della Costituzione. Napoli: Editoriale Scientifica, 2014, pp 7 et 44 et seqq.

GABDIN, D. Droit de l'alimentation et droit agricole européens: quelles articolation? Revue européenne de droit de la consomation 2:243 et seqq, 2011.

GHIAZZA, S. Cibo e/è Cultura.Quaderni di Ateneo, vol XV, Bari, Università degli Studi di Bari Aldo Moro, 2015.

GUSMAI, A. Giurisdizione, interpretazione e co-produzionenormativa.Cacucci, Bari, 47 et seqq, $2015^{\mathrm{a}}$.

GUSMAI, A. Il diritto fondamentale al cibo adeguato per illusioni e realtà. Diritti fondamentali.it: Dottrina, 2015b. <http://www.dirittifondamentali.it/unicas_df/>. Accessed 25 Jan 2016

HARDIN, G. The Tragedy of the Commons. Science, 162:1243-1248, 1968.

JANNARELLI, A. Profili Giuridici del sistema agro-alimentare trascesa e crisi della globalizzazione. Bari: Cacucci, 2011, p 299-325

LINEBAUGH, P. The Magna Charta Manifesto. Liberties and Commons for All. Berkeley: UCLA Press, 2008.

LUCARELLI, A. La democrazia dei beni comuni. Nuove Frontiere del diritto pubblico.. RomaBari: Laterza, 2013.

LUCARELLI, A. Beni Comuni e funzioni sociali della proprietà. Il ruolo del Comune, in Benicomuni e cooperazione. In: SACCONI, L.; OTTONE, S. (eds) Benicomuni e cooperazione. Bologna: Il Mulino, 2015.

LUCIANI, M. Funzioni e responsabilità della giurisdizione. Unavicendaitaliana (e non solo).Rivista AIC 3:3, 2012.

MARELLA, M. R. Oltre Il Pubblico e privato. Per undirittodei beni comuni. Verona: Ombre Corte, 2012.

MARX, K. Lineamenti Fondamentali di critical'economia política. Roma: Manifestolibri, 2012.

MATTARELLA, S. Intervento del Presidente Della Repubblica Sergio Mattarella Allá cerimonia conclusiva di EXPO 2015. <http://www.quirinale.it/elementi/Continua.aspx?tipo= Discorso\&key $=143>$. Accessed 25 Jan 2016

MATTEI, U. Bem icomuni. Un manifesto. Roma-Bari: Laterza, 2012.

MATTEI, U. Senza proprietà non c'elibertà (Falso!). Roma-Bari: Laterza, 2014.

Right to food and "tragedy" of the commons 
MAZZUCATO, M. Lo Stato innovatore. Sfatare il mito del pubblico controil privato. Roma-Bari: Laterza, 2014.

MECHLEM, K. Food, Right to, International Protection. Max Planck Encyclopedia of Public International Law, 2008.

MORTATI, C. Costituzione Dello Stato (dottrine generali e Costituzione Della Repubblica italiana).Encdir, vol XI.Milano: Giuffrè, 1962, 222 et seqq.

NIVARRA, L. (2012) Alcune riflessioni sulrapportofra pubblico e privato. In: MARELLA, M. R. (ed) Ol treil pubblico e il privato. Per um diritto dei beni comuni. Verona: Ombre Corte, 85 et seqq.

OSTROM, E. Governing the Commons: The Evolution of Institutions for Collective Action. Cambridge: Cambridge University Press, 1990.

OSTROM, E. A Behavioral Approach to the Rational Choice Theory of Collective Action. Amer Political Science Review, 1998, 91:1-22

OSTROM, E. A general framework for analyzing sustainability systems. Science, 2009, 325: 419 et seqq.

PATEL, R. The Value of Nothing: how to Reshape Market Society and Redefine Democracy. London: Portobello Books, 2009.

RODOTÀ, S. Il terribile diritto: studi sul La proprietà privata e ibeni comuni. Bologna: Il Mulino, 2013.

RUGGERI, A. Come costruire e preservare la tradizioni dei diritti in Europa? II seminario annuale di Diritti Comparati "Costruendo le tradirioni dei diritti in Europa", Macerata 11 dicembre 2015a. <http://www.dirittifondamentali.it/unicas_df/>. Accessed: 25 jan. 2016

RUGGERI, A. Peruno studio sui dirittisociali e sulla Costituzione come sistema (notazioni di metodo). Consulta On Line, Fasc. II, 2015b, 541 et seqq.

RUGGERI, A.; SPADARO, A. Dignità dell' uomo e giurisprudenza costituzionale (prime notazioni). Politica del diritto, 1991, 3: 343-377

SACCONI, L. Beni comuni, contratto sociale e governance cooperativa dei servizi pubblicilo cali. In: SACCONI, L.; OTTONE, S. (eds) Beni comuni e cooperazione. Bologna: Il Mulino, 2015, 175 et seqq.

SANCHEZ, L. Darwin, Artificial Selection, and Poverty. Contemporary Implications of a Forgotten Argument. 29 Politics and the Life Sciences 1:61-75, 2010.

SARACENO, C. Il lavoronon basta. La povertà in Europa neglianni della crisi. Feltrinelli, Milano, 2015. 
SEGRÉ, A. Politiche per lo sviluppo agricolo e la sicurezza alimentare. Roma: Carrocci Editore, 2011.

STAIANO, S. Note sul diritto fondamentale all'acqua. Proprietà del bene, gestione del servizio, ideologie della privatizzazione. Federalismi. it: Rivista di Diritto Pubblico italiano, comparato, europeo 5:21, 2011. <http://www.federalismi.it. Accessed>. 25 Jan 2016

STIGLITZ, J. E. The Price of Inequality: How Today's Divided Society Endangers Our Future. New York-London: W.W. Norton \& Company, 2012.

VITALE, E. (2013) Controi bem icomuni: uma critica illuministica. Roma-Bari: Laterza, 2013.

WEBER, M. Der Sinn der "Wertfreiheit" der soziologischen und ökonomischen Wissenschaften. Logos. Internationale Zeitschriftfürphilosophie der kultur 7(1), 1917.

ZAGREBELSKY, G.; MARCENÒ, V. Giustiziacostiturionale. Bologna: Il Mulino, 2012.

Recebido em: 10/03/2016.

Aprovado em: 20/04/2016. 
